\title{
Evaluasi Penerapan Konsep Ekowisata di Kampung Wisata Arborek, Raja Ampat
}

\author{
Evaluation of the Implementation of the Ecotourism Concept \\ in Arborek Village, Raja Ampat
}

\author{
Novelina Tampubolon $^{1 *}$, Maria Mardia Marampa ${ }^{2}$, Marjan Bato ${ }^{1}$ \\ ${ }^{1}$ Jurusan Perikanan, FPIK - UNIPA, Jalan Gunung Salju, Amban, Manokwari, 98314, Indonesia \\ ${ }^{2}$ Program Studi D3 Ekowisata, FPIK - UNIPA, Raja Ampat, 98482, Indonesia \\ *Korespondensi: novelinatampubolon@gmail.com
}

\begin{abstract}
ABSTRAK
Evaluasi penerapan konsep ekowisata pada sebuah destinasi wisata dinilai penting dalam menjaga keberlanjutan pengelolaan wisata. Kampung wisata Arborek tmerupakan salah satu kampung wisata terbaik di Raja Ampat sehingga pemilihan sebagai lokasi penelitian dirasa tepat untuk mengevaluasi penerapan konsep ekowisata pada setiap kegiatan wisata sehingga eksistensi Kampung W isata Arborek tetap terjaga. adapun tujuan penelitian ini adalah mengevaluasi penerapan konsep ekowisata di kampung wisata Arborek. Data diambil menggunakan kuisioner closed ended selanjutnya dianalisis dengan menggunakan metode One Score One Criteria Scoring System. Hasil penelitian menunjukkan bahwa pengelola wisata di Kampung Wisata Arborek telah memahami konsep ekowisata; memiliki keunikan dan ciri khas, adanya daya dukung masyarakat, pemerintah dan memiliki nilai jual. Sama halnya dengan persepsi masyarakat yang menyatakan bahwa dari sisi keadaan kampung, dampak kegiatan wisata bagi masyarakat dan fasilitas wisata rata-rata memiliki skor 6 yang artinya adalah baik. Persepsi yang sama diutarakan oleh wisatawan dari sisi fasilitas dan aksesbilitas yaitu skor 6 (baik) sedangkan untuk aspek atraksi wisata wisatawan menyatakan skor 7 yang artinya sangat baik. Secara umum, Kampung Wisata Arborek telah menerapkan konsep ekowisata dengan baik, Namun untuk menjaga keberlanjutan kegiatan wisata diperlukan kerjasama antar stakeholder yang terlibat (masyarakat, pemerintah dan NGO) sehingga keberlanjutan Kampung Wisata Arborek tetap terjaga.
\end{abstract}

Kata kunci: Ekowisata; Evaluasi; Kampung wisata arborek; Raja Ampat

\begin{abstract}
Evaluation the application of the ecotourism concept in a tourist destination is considered important in maintaining the sustainability of tourism management. Arborek tourism village is one of the best tourist villages in Raja Ampat so that the selection as a research location is considered appropriate to evaluate the application of the ecotourism concept to every tourist activity so that the existence of Arborek Tourism Village is maintained. The purpose of this study is to evaluate the application of the ecotourism concept in the Arborek tourist village. The data was taken using a closed ended questionnaire and then analyzed using the One Score One Criteria Scoring System method. The results showed that tourism managers in Arborek Tourism Village had understood the concept of ecotourism; has a unique and distinctive characteristic, the existence of the carrying capacity of the community, government and has a selling value. It is the same with public perception which states that in terms of village conditions, the impact of tourism activities on the community and tourist facilities has an average score of 6 which means it is good. The same perception was expressed by tourists in terms of
\end{abstract}


facilities and accessibility, namely a score of 6 (good) while for the tourist attraction aspect, tourists stated a score of 7 which means very good. In general, Arborek Tourism Village has implemented the concept of ecotourism well, however, to maintain the sustainability of tourism activities, cooperation between stakeholders involved (community, government and NGOs) is needed so that the sustainability of Arborek Tourism Village is maintained.

Keywords: Ecotourism; Evaluation; Arborek tourism village; Raja Ampat

\section{PENDAHULUAN}

Ekowisata bukan hanya sekedar melakukan perjalanan wisata ke alam melainkan sebagai roh dan jiwa dari aktivitas wisata yang dilaksanakan wisatawan di destinasi wisata dengan menegakkan 7 (tujuh) pilar utama yaitu 1) ekologi, 2) sosial budaya, 3) ekonomi, 4) pengalaman, 5)kepuasan, 6) kenangan dan 7) pendidikan (Avenzora et al, 2013). Salah satu destinasi unggulan di Indonesia adalah Kepulauan Raja Ampat. Hal ini didukung oleh pernyataan Nikijuluw dkk (2017) bahwa Raja Ampat merupakan salah satu kepulauan yang memiliki terumbu karang terbaik di dunia sehingga dijului sebagai jantung segitiga karang dunia (Heart of The Coral Triangle). tidak hanya keindahan bawah laut namun hamparan padang lamun, hutan mangrove, pantai berpasir dan pantai tebing berbatu juga menjadi ciri khas dari Kepulauan Raja Ampat. Tak hanya wisata bahari, Raja Ampat juga memiliki wisata dari segi atraksi budaya dan kehidupan asli masyarakat lokal.

Kekayaan alam yang berlimpah menjadikan Raja Ampat sebagai salah satu destinasi unggulan yang banyak dikunjungi oleh para wisatawan baik wisatawan lokal maupun mancanegara. Sehingga diperlukan bentuk kegiatan wisata yang tidak hanya mengedepankan aspek ekonomi namun aspek ekologi dan sosial budaya tetap dijaga. Ekowisata menjadi solusi dari kegiatan wisata yang mengedepankan tiga aspek tersebut. Pernyataan ini didukung oleh TIES (2002) bahwa ekowisata tidak hanya berwisata pada area-area alami namun sekaligus untuk melakukan kegiatan konservasi lingkungan, budaya dan juga memperhatikan kesejahteraan dari masyarakat di sekitar destinasi wisata. Namun, pengelolaan yang salah akan berimplikasi pada terancamnya eksistensi sumber daya alam (Choi \& Sirakaya, 2006). Pendapat yang sama juga diutarakan oleh Tsaur \& Lin (2006) bahwa apabila pengelolaan ekowisata tidak menerapkan prinsipprinsip pelestarian yang bertanggungjawab secara tepat pada sumber daya alam yang dijadikan sebagai objek daya tarik utama maka kegiatan ekowisata akan berdampak buruk pada lingkungan destinasi wisata.

Raja Ampat memiliki 4 (empat) kampung wisata yang telah di SK kan oleh pemerintah daerah yaitu Kampung Wisata Yenwaupnor dan Sawingrai dikenal dengan pesona burung cendrawasih, wisatawan dapat menyaksikan burung cedrawasih (bird watching), Kampung Wisata Arborek dikenal melalui atraksi Ikan Pari (Manta), Kampung Wisata Sauwandarek terkenal dengan rumahrumah penduduknya yang masih berbentuk asli tempo dulu dengan atap dari daun yang masih asli. Arborek menjadi Kampung Wisata terbanyak pengunjung wisatawannya 
dibandingan 3 kampung wisata lainnya.

Keberhasilan dari Kampung Arborek dalam membuat peraturan daerah, sekaligus pemberian nama kawasan konservasi yaitu Mambarayup dan Indip yang dibantu para stakeholder (pemerintah pusat, daerah, pusat penelitian dan organisasi non pemerintah menjadikan Kampung Arborek sebagai pionir bagi 18 kampung wisata lainnya dalam melakukan konservasi kekayaan laut yang berbasis masyarakat, masyarakat. Kampung Arborek merupakan salah satu spot diving terbaik di Raja Ampat untuk bertemu dengan Ikan Pari. Melihat keberhasilan dari Kampung Arborek dibandingkan dengan 3 kampung lainnya, maka diperlukan evaluasi apakah implementasi ekowisata di Kampung Arborek telah sesuai dengan konsep ekowisata sehingga keberlanjutan kegiatan ekowisata di Kampung Arborek tetap terjaga.

\section{METODE PENELITIAN}

\section{Lokasi dan Waktu}

Penelitian dilaksanakan di Kampung Arborek Distrik Meos Mansar Kabupaten Raja Ampat pada bulan Desember 2021 - Februari 2021.

\section{Alat dan Objek Penelitian \\ Alat yang digunakan pada penelitian adalah kuisioner, daftar pertanyaan, alat tulis, kamera, dan leptop sedangkan untuk objek penelitian adalah pengelola, masyarakat dan wisatawan.}

\section{Teknik Pengambilan dan Analisis Data}

Pengambilan data dilakukan dengan menggunakan kuisioner yang dinilai dan dianalisis dengan metode
One Score-One Criteria System dengan rentang skala 1-7 ( $1=$ Sangat buruk 2 = buruk 3= Agak buruk 4=Biasa saja 5=Agak baik 6=Baik $7=$ Sangat baik). Karakter masyarakat Indonesia yang sangat rinci dalam memberikan sebuah penilaian maka penggunaan skala 1-7 tepat untuk diterapkan (Avenzora, 2008). Data diambil pada 3 kategori responden yaitu; pengelola, masyarakat, dan wisatawan dengan jumlah responden masing-masing 10 orang per kategori dengan teknik simple random sampling sehingga jumlah keseluruhan responden adalah 30 responden.

\section{HASIL DAN PEMBAHASAN}

\section{Evaluasi Penerapan Ekowisata Berdasarkan Persepsi Masyarakat}

Persepsi ini didasarkan pada kondisi kegiatan ekowisata yang ada di kampung Arborek; responden memberikan penilaian terhadap penerapan konsep ekowisata. Selain itu, ekowisata merupakan jenis pariwisata berkelanjutan dimana aktor utama dalam kegiatan pengelolaannya adalah masyarakat lokal di kawasan wisata. Hal ini didukung oleh pernyataan Kosmaryandi (2008) bahwa pelibatan masyarakat lokal sebagai pelaku dari kegiatan wisata menjadi tanda bahwa konsep ekowisata bukan lagi bentuk pengelolaan yang sentralistik.

\section{Kondisi Kampung Wisata}

Berdasarkan analisis data responden, mayoritas responden mempersepsikan bahwa kriteria untuk keadaan fisik kampung yang terdiri dari kondisi kampung, kebersihan kampung, penataan kampung wisata dan ternobatnya Arborek sebagai kampung wisata memiliki skor 6 
(enam) yang artinya baik. Secara rinci dapat dilihat pada Tabel 1.

\section{Dampak Kegiatan Wisata}

Responden mempersepsikan bahwa masyarakat yang ada di sekitar lokasi wisata turut merasakan dampak dari kegiatan wisata seperti meningkatkan perekonomian masyarakat lokal (67\%) dan membuka lapangan pekerjan baru (20\%); saat ini, mayoritas masyarakat bekerja sebagai pelaku wisata seperti pengelola homestay, divers, guide dan pembuat kerajinan tangan sehingga melalui keterlibatan masyarakat sebagai pelaku wisata di Kampung Arborek berdampak pada peningkatan ekonomi masyarakat.. Hal yang sama dikemukakan oleh (Nuraini dkk, 2018) bahwa Pertama, melalui penyewaan alat snorkeling, diving, speedboat/longboat dan fasilitas wisata lainnya kepada wisatawan yang berkunjung ke kawasan Kampung Arborek, masyarakat sebagai pengelola ekowisata mendapatkan tambahan penghasilan. Kedua, pihak swasta hanya diizinkan untuk menyediakan liveboard yang berhenti di sekitar kawasan Kampung Arborek, hal ini sebagai salah satu strategi untuk membawa wisatawan untuk melakukan aktivitas wisata di Kampung Arborek seperti menikmati pasir putih di pantai Arborek, snorkeling, keliling kampung hingga membeli souvenir berupa hasil kerajinan tangan masyarakat lokal seperti noken dan kayakyof. Ketiga, kegiatan wisata tidak hanya berkontribusi pada pembangunan kampung namun juga dalam pembangunan daerah. Dampak kegiatan wisata tersebut setelah dianalisis mayoritas masyarakat mempersepsikan bahwa indikator partisipasi masyarakat sampai dengan nilai jual barang dan jasa memiliki skor 6 (enam) yang artinya baik. Secara rinci dapat dilihat pada Tabel 2.

Tabel 1. Keadaan fisik kampung berdasarkan persepsi masyarakat

\begin{tabular}{llllllllllllc}
\hline \multicolumn{1}{c}{ Kriteria } & \multicolumn{11}{c}{ Skor } & Rata-Rata \\
\hline Kondisi kampung & 6 & 6 & 6 & 6 & 6 & 6 & 7 & 6 & 6 & 6 & 6 \\
Kebersihan & 6 & 6 & 6 & 7 & 6 & 6 & 6 & 6 & 6 & 6 & 6 \\
Penataan kawasan wisata & 6 & 6 & 7 & 6 & 6 & 6 & 7 & 6 & 5 & 6 & 6 \\
Arborek sebagai kampung & 6 & 6 & 6 & 7 & 6 & 7 & 7 & 4 & 6 & 7 & 6 \\
wisata & & & &
\end{tabular}

Ket: $1=$ Sangat buruk $2=$ buruk 3= Agak buruk 4=Biasa saja 5=Agak baik $6=$ Baik $7=$ Sangat baik

Tabel 2. Dampak kegiatan wisata

\begin{tabular}{lccccccccccc}
\hline \multicolumn{1}{c}{ Dampak kegiatan wisata } & \multicolumn{11}{c}{ Skor } \\
\hline Partisipasi masyarakat & 6 & 6 & 6 & 7 & 5 & 7 & 7 & 7 & 6 & 6 & 6 \\
Keuntungan ekonomi & 6 & 6 & 6 & 7 & 6 & 5 & 5 & 4 & 6 & 6 & 6 \\
Sosial budaya & 6 & 6 & 6 & 6 & 6 & 7 & 7 & 6 & 6 & 6 & 6 \\
Ramah lingkungan & 6 & 6 & 6 & 6 & 6 & 7 & 7 & 7 & 6 & 6 & 6 \\
Nilai jual barang dan jasa & 6 & 6 & 6 & 6 & 6 & 6 & 6 & 6 & 6 & 7 & 6 \\
\hline
\end{tabular}

Ket: $1=$ Sangat buruk $2=$ buruk 3= Agak buruk 4=Biasa saja 5=Agak baik $6=$ Baik $7=$ Sangat baik 


\section{Fasilitas Wisata}

Berdasarkan analisis data, responden menilai bahwa fasilitas wisata yang ada memiliki skor 6 (enam) yang artinya baik. Sama halnya dengan sikap masyarakat terhadap pengunjung dan partisipasi masyarakat dalam kegiatan ekowisata di Kampung Arborek dengan nilai rata rata skor 6 (enam). Hal ini menunjukkan bahwa masyarakat sudah terlibat penuh dengan kegaitan ekowisata di Kampung Arborek. dengan kata lain prinsip ekowisata diterapkan dengan baik di Kampung Wisata Arborek. Selain itu, responden menyatakan bahwa ada beberapa fasilitas yang perlu dibenahi (Tabel 3).

\section{Evaluasi Penerapan Ekowisata Berdasarkan Persepsi Pengelola}

Hasil analisis data menunjukkan bahwa responden menilai masyarakat mendukung dan ikut berpartisipasi dalam kegiatan wisata setelah kampung Arborek dinobatkan sebagai kampung wisata sehingga kegiatan wisata berjalan dengan baik. Selain itu, data dilapangan menunjukkan bahwa masyarakat telah memahami konsep ekowisata yan sesungguhnya. Responden menyatakan bahwa prinsip ekowisata adalah memiliki keunikan dan ciri khas, adanya daya dukung masyarakat, pemerintah dan memiliki nilai jual. Secara rinci dapat dilihat pada Tabel 4.

\section{Homestay}

Kampung Arborek memiliki 2 homestay pasif dan 9 homestay aktif yang masih beroperasi sampai saat ini serta pengelolaan homestay secara garis besar telah dilaksanakan dengan memperhatikan kebersihan kenyaman dan keamanan. Kebersihan homestay telah mencerminkan standar homestay mulai dari kebersihan kamar mandi dan kualitas air serta kebersihan dan kehigienisan makanan yang disedikan. yang disediakan dari pihak pengelola Pengelolaan homestay itu sendiri diperlukan untuk memenuhi serta meningkatkan lama tinggal wisatawan dan juga meningkatkan kepuasan wisatawan dalam menikmati daya tarik wisata yang ada di Kampung Arborek. Sama halnya dengan yang dikemukakan (Puspitasari, 2019) bahwa keberadaan homestay menjadi salah satu faktor yang mempengaruhi minat kunjungan wisatawan ke destinasi wisata asalkan pengelolaan homestay dilakukan secara profesional. Homestay yang nyaman akan memberikan peluang bagi wisatawan tinggal lebih lama untuk menikmati alam dan mengenal tradisi dan budaya di destinasi wisata.

Tabel 3. Saran responden terkait pembenahan fasilitas wisata

\begin{tabular}{lll}
\hline N & \multicolumn{1}{c}{ Saran pembenahan wisata saat wisatawan meningkat } & Persentase \\
o. & \multicolumn{1}{c}{ Fasilitas yang memadai (restoran, homestay dan toilet) } & $50 \%$ \\
2 & Keamanan wisatawan (pos penjagaan) & $30 \%$ \\
3 & $\begin{array}{l}\text { Kenyamanan (tempat sampah, sarana ibadah, tempat duduk, } \\
\text { gazebo) }\end{array}$ & $20 \%$ \\
\hline
\end{tabular}

Tabel 4. Persepsi pengelola tentang ekowisata

\begin{tabular}{llc}
\hline No. & Lokasi yang sesuai dengan kaidah ekowisata & Persentase \\
\hline 1 & memiliki keunikan dan ciri khas, adanya daya dukung & $60 \%$ \\
& masyarakat, pemerintah dan memiliki nilai jual & \\
2 & memiliki panorama yang indah dan alami & $30 \%$ \\
3 & Memiliki habitat dan ekosistem beragam & $30 \%$ \\
4 & Adanya sarana dan prasarana & $10 \%$ \\
\hline
\end{tabular}


Homestay yang ada di Kampung Arborek adalah milik masyarakat itu sendiri sehingga pengelolaannya lebih pada kekeluargaan. Pemilik homestay mempekerjakan keluarga sendiri untuk mengelola dan melayani para tamu yang tinggal di homestay. pemilik homestay hanya mengontrol jalannya pengelolaan homestay yang dilakukan oleh pelayan yang dipekerjakan di homestay baik itu bagian masak dan penyajian makanan bagi wisatawan maupun kebersihan di kamar dan kamar mandi/toilet.

Pengelola homestay juga menyediakan fasilitas di dalam kamar tidur seperti kipas angin, meja kecil, kursi, single/double bed, selimut, kelambu, bantal/guling, stop kontak dan tempat sampah kecil. Sedangkan untuk diluar kamar homestay pengelola menyediakan tempat sampah, kamar mandi, tempat duduk dan ayunan untuk bersantai. Berdasarkan hal di atas dapat disimpulkan bahwa pengelola homestay telah memahami konsep pengelolaan homestay, mulai dari penyambutan tamu, pelayanan (kebersihan dan keramahan) hingga pengaturan menu makanan bagi wisatawan. Selain itu, masyarakat telah menjalankan pengelolaan homestay dengan prinsip pemberdayaan masyarakat lokal.

\section{Evaluasi Penerapan Ekowisata Berdasarkan Persepsi Wisatawan}

\section{Atraksi wisata}

Kampung Arborek memiliki kekayaan objek wisata alam mulai dari wisata laut, pantai dan wisata budaya. Wisata pantai sendiri yakni berenang, snorkling dan diving dan Kampung Arborek sendiri merupakan titik area untuk dapat melihat Pari Manta. Secara rinci dapat dilihat pada Gambar 2.

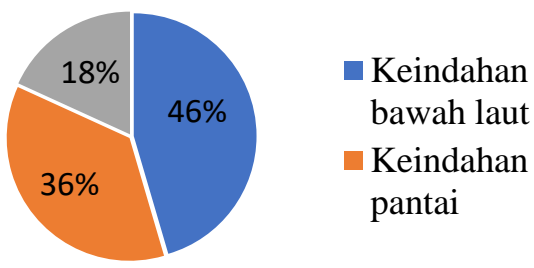

\section{Gambar 1. Jenis atraksi wisata di kampung arborek}

Gambar 1 menjelaskan bahwa 46\% wisatawan melakukan kunjungan ke kampung wisata Arborek untuk melihat keindahan bawah laut dan keindahan pantai termasuk bertemu dengan Pari Manta; ada aturan yang berlaku dan dibatasi dalam rentan 1 jam maksimal 20 penyelam untuk mengeksplorasi Manta Sandy. Snorkling untuk melihat keindahan spesies ikan; di bawah jembatan utama kampung Arborek merupakan area schooling fish. Selain itu, tanpa snorkeling wisatawan sudah dapat melihat keindahan terumbu karang. Selain itu ada pula wisata budaya seperti tarian yang dimainkan oleh anak-anak, suling tambur dan cakalele yang dimainkan pada saat penyambutan para tamu besar dan juga untuk acara adat. Menurut responden sebanyak $70 \%$ kaum perempuan merupakan pengrajin souvenir. Wisatawan tidak hanya menikmati keindahan alam kampung Arborek namun juga melakukan kegiatan konservasi lingkungan. Selain itu, para wisatawan juga berinteraksi dengan masyarakat lokal untuk mengenal kehidupan masyarakat kampung mulai dari belajar membuat papeda, balobe (kegiatan mencari ikan di malam hari dengan menggunakan tombak dan senter) hingga belajar membuat kerajinan/anyaman.

Berdasarkan analisis data responden, wisatawan mempersepsikan bahwa kriteria budaya lokal, pemandangan alam, keindahan bawah laut dan atraksi pari manta di Kampung Arborek memiliki skor 7 (tujuh) yang artinya adalah sangat baik. Sedangkan 
untuk kriteria daya tarik wisata, variasi cinderamata dan tumbuh-tumbuhan sebagai bagian dari atraksi wisata memiliki skor 6 (enam) yang artinya dinilai baik. Secara rinci dapat dilihat pada Tabel 5 .

\section{Keunikan atau Kekhasan}

Hasil analisis data menunjukkan bahwa $33 \%$ responden menyatakan Pari Manta dan diving (penyelaman) adalah paket wisata yang khas di Kampung Arborek. Selain itu, 17\% responden lainnya menyatakan adanya keindahan bawah, 9\% keindahan pantai dan $8 \%$ menyatakan adanya budaya masyarakat lokal. Dengan demikian, Pari Manta dan diving untuk melihat keindahan terumbu karang menjadi atraksi unggulan di Kampung Arborek.

\section{Kesenian Cenderamata}

Adapun persepsi wisatawan untuk kriteria kesenian cinderamata memiliki skor 6 (enam) yang artinya baik. Hal ini dibuktikan dengan kampung wisata Arborek memiliki variasi cinderamata yang beragam (Tabel 6).

Tabel 5. Persepsi wisatawan terhadap atraksi wisata

\begin{tabular}{lllllllllllc}
\hline \multicolumn{11}{c}{ Atraksi Wisata } & \multicolumn{11}{c}{ Skor } \\
\hline Variasi cinderamata & 7 & 4 & 5 & 7 & 6 & 7 & 3 & 6 & 6 & 5 & 6 \\
Daya tarik wisata & 7 & 4 & 6 & 7 & 7 & 7 & 7 & 6 & 7 & 6 & 6 \\
Budaya lokal & 7 & 6 & 7 & 6 & 7 & 7 & 6 & 6 & 7 & 7 & 7 \\
Pemandangan alam & 7 & 7 & 7 & 7 & 7 & 4 & 7 & 7 & 7 & 7 & 7 \\
Tumbu-tumbuhan & 6 & 7 & 6 & 6 & 6 & 6 & 5 & 6 & 6 & 5 & 6 \\
Keindahan bawah laut & 7 & 7 & 7 & 7 & 7 & 7 & 6 & 7 & 7 & 7 & 7 \\
Atraksi Pari Manta & 7 & 7 & 7 & 6 & 6 & 7 & 6 & 7 & 7 & 7 & 7 \\
\hline
\end{tabular}

Ket: $1=$ Sangat buruk 2 = buruk 3=Agak buruk 4=Biasa saja 5=Agak baik 6=Baik $7=$ Sangat baik

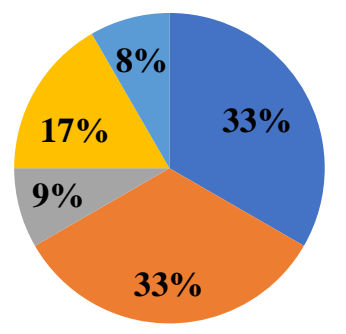

$\square$ Diving

Pari manta

- Keindahan pantai

- Keindahan bawah laut

- Budaya Masyarakat Lokal

Gambar 2. Atraksi wisata yang unik/khas

Tabel 6. Jenis cenderamata Kampung Arborek

\begin{tabular}{|c|c|c|c|}
\hline No. & Jenis cinderamata & Bahasa & Jenis bentuk \\
\hline & & Lokal & \\
\hline 1 & Tikar & Yaer & $\begin{array}{l}\text { Tikar Lipat (yaer yaper) } \\
\text { Tikar gulung (yaer kamon) }\end{array}$ \\
\hline 2 & Topi & Kayafiof & $\begin{array}{l}\text { Topi dengan bentuk Pari Manta } \\
\text { Topi gelombang } \\
\text { Topi bentuk ikan Raja (interar) } \\
\text { Topi biasa }\end{array}$ \\
\hline 3 & Kalung & & Mata kalung berbentuk Pari Manta \\
\hline 4 & Bakul & Bayai & Kotak \\
\hline
\end{tabular}




\begin{tabular}{rlll}
5 & Tas anyaman & Noken & Noken kebun \\
& & Gelombang \\
& & Biasa \\
& & Laptop \\
& & Berbentuk bulat \\
\hline
\end{tabular}

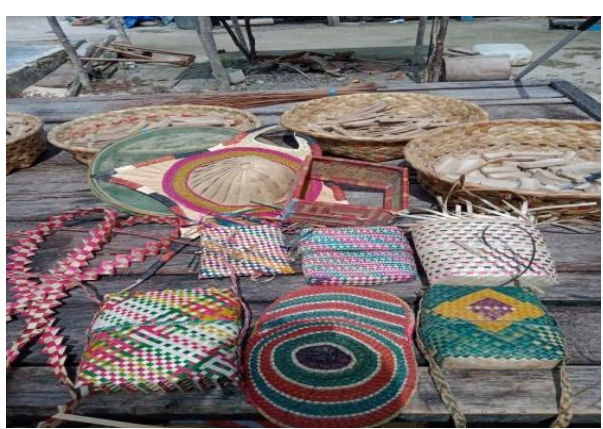

Gambar 3. Kesenian cenderamata

\section{Fasilitas}

Aspek berikut yang harus diperhatikan dalam mengembangkan ekowisata yakni fasilitas. Data di lapangan menunjukkan bahwa mayoritas wisatawan mempersepsikan kriteria untuk fasilitas wisata kampung Arborek berupa tempat sampah, kondisi fasilitas yang ada, sarana informasi, kesehatan, hiburan, kebersihan, keamanan dan pelayanan pengelola kampung memiliki skor 6 (enam) yang artinya baik. Sedangkan homestay dan tempat ibadah memiliki skor 7 (tujuh) yang artinya sangat baik. Adapun kios makanan dan minuman serta air bersih memiliki skor
4 (empat) yang artinya biasa saja, hal ini menurut responden dikarenakan kampung Arborek belum ada sarana air bersih dan warung makan sehingga untuk saat ini masyarakat menggunakan air hujan untuk kebutuhan sehari-hari seperti memasak, mencuci bahan makanan dan dimasak untuk menjadi air minum. Fasilitas toilet/MCK memiliki skor 5 (lima) yang artinya adalah agak baik. Hal ini karena fasilitas yang ada cukup baik dapat digunakan oleh berbagai kalangan tanpa ada batasan (Tabel 7)

Tabel 7. Hasil penilaian wisatawan terhadap fasilitas wisata di kampung arborek

\begin{tabular}{lccccccccccc}
\hline \multicolumn{1}{c}{ Fasilitas } & \multicolumn{1}{c}{ Skor } & \multicolumn{1}{c}{ Rata-Rata } \\
\hline Kondisi Fasilitas yang ada & 7 & 4 & 6 & 7 & 6 & 6 & 6 & 6 & 6 & 6 & 6 \\
Air bersih & 4 & 3 & 3 & 3 & 6 & 7 & 1 & 5 & 5 & 5 & 4 \\
Penginapan/homestay & 7 & 6 & 6 & 7 & 7 & 7 & 7 & 6 & 7 & 7 & 7 \\
Toilet/MCK & 7 & 3 & 6 & 5 & 3 & 4 & 4 & 6 & 7 & 6 & 5 \\
Tempat sampah & 6 & 6 & 6 & 6 & 7 & 5 & 7 & 6 & 6 & 5 & 6 \\
Tempat ibadah & 7 & 6 & 6 & 7 & 6 & 7 & 7 & 6 & 7 & 7 & 7 \\
Kios makanan dan minuman & 7 & 4 & 5 & 6 & 1 & 6 & 1 & 5 & 5 & 5 & 4 \\
Sarana informasi & 7 & 4 & 7 & 6 & 7 & 7 & 7 & 5 & 6 & 5 & 6 \\
Sarana kesehatan & 7 & 6 & 6 & 5 & 5 & 7 & 4 & 6 & 7 & 6 & 6 \\
Tingkat kebersihan & 7 & 6 & 7 & 7 & 6 & 7 & 7 & 6 & 6 & 6 & 6 \\
Jaminan keamanan & 7 & 7 & 7 & 7 & 6 & 7 & 7 & 6 & 7 & 6 & 6 \\
Sarana hiburan & 7 & 4 & 6 & 5 & 6 & 7 & 6 & 6 & 7 & 6 & 6 \\
Pelayanan masyarakat & 7 & 6 & 6 & 6 & 6 & 7 & 6 & 6 & 7 & 6 & 6 \\
Pelayanan pengelola kampung & 7 & 5 & 6 & 6 & 6 & 6 & 6 & 7 & 7 & 6 & 6 \\
\hline
\end{tabular}

\section{Aksesbilitas}

Aspek ke 3 (tiga) yang perlu di perhatikan dalam pengembangan ekowi- 
sata yakni aksesbilitas. Aksesbilitas adalah bagaimana seseorang mendapatkan keamanan dan kenyamanan serta kemudahan untuk tiba di sebuah tujuan. Aksesbilitas dalam sebuah kegiatan wisata sangat penting karena mempengaruhi kenyamanan wisatawan dalam melakukan perjalanan menuju destinasi wisata. semakin tinggi aksesbilitas maka semakin tinggi juga kenyamanan wisatawan dalam melakukan perjalanan wisata. Berdasarkan analisis data responden, $100 \%$ wisatawan mempersepsikan bahwa kriteria untuk aksesbilitas wisata kampung Arborek memiliki skor 6 (enam) yang artinya baik. Secara rinci dapat dilihat pada Tabel 8 .

Pada Tabel 8 di atas menjelaskan bahwa akses menuju kampung wisata baik dan cukup mudah namun hanya melalui jalur laut dengan menggunakan speedboat atau perahu. Jarak ke Ibu kota kecamatan (Yenbekwan) dapat ditempuh menggunakan logboat atau speed boat kurang lebih 20 menit sedangkan untuk menuju Ibu kota kabupaten (Raja Ampat) dapat ditempuh selama 1- 2 jam dan untuk menuju ke ibu kota provinsi (Sorong) dapat ditempuh selama $4-5$ jam. Wisatawan yang berkunjung $50 \%$ menggunakan transportasi yang di sewa dan 50\% menggunakan perahu tidak disewa yang merupakan milik kerabat ataupun keluarga. Namun apabila wisatawan membutuhkan transportasi masyarakat maka biayanya yakni Rp 1.000 .000 untuk pulang-pergi.

Tabel 8. Penilaian wisatawan terhadap aksesbilitas menuju kampung arborek

\begin{tabular}{lccccccccccc}
\hline \multicolumn{1}{c}{ Aksesbilitas } & \multicolumn{11}{c}{ Skor } \\
\hline Kondisi jalan & 7 & 6 & 6 & 6 & 6 & 7 & 5 & 6 & 6 & 5 & 6 \\
Transportasi laut & 7 & 4 & 6 & 6 & 6 & 7 & 4 & 6 & 6 & 7 & 6 \\
$\begin{array}{l}\text { Biaya (Transport, tiket, } \\
\text { konsumsi) }\end{array}$ & 7 & 5 & 6 & 5 & 6 & 7 & 7 & 6 & 6 & 5 & 6 \\
Jembatan & 7 & 5 & 6 & 7 & 6 & 7 & 7 & 6 & 6 & 6 & 6 \\
$\begin{array}{l}\text { Tata ruang kampong } \\
\text { Ketersediaan }\end{array}$ & 7 & 6 & 7 & 6 & 6 & 7 & 5 & 6 & 7 & 5 & 6 \\
transportasi & 7 & 5 & 6 & 6 & 6 & 7 & 3 & 6 & 6 & 7 & 6 \\
\hline
\end{tabular}

\section{KESIMPULAN}

Secara umum 7 (tujuh) pilar ekowisata telah diterapkan dalam pengelolaan Kampung Wisata Arborek. Hasil penelitian menunjukkan bahwa responden kategori masyarakat menyatakan keadaan kampung sebagai destinasi wisata, dampak kegiatan wisata dan fasilitas wisata rata-rata memiliki skor 6 yang artinya adalah baik. Sejalan dengan persepsi pengelola yang menyatakan bahwa kegiatan wisata di Kampung Wisata Arborek memiliki keunikan dan ciri khas, adanya daya dukung masyarakat, pemerintah dan memiliki nilai jual. Tidak berbeda jauh dengan persepsi wisatawan yang berpendapat bahwa atraksi wisata di
Kampung Arborek memiliki skor 7 yang artinya adalah sangat baik. Sedangkan untuk fasilitas dan aksesbilitas memiliki skor 6 yang artinya adalah baik. Wisatawan juga mempersepsikan bahwa pengelola dan masyarakat telah memiliki kepedulian, tanggung jawab, dan komitmen untuk menjaga keberlanjutan kegiatan wisata di Kampung Arborek.

\section{UCAPAN TERIMA KASIH}

Terimakasih peneliti sampaikan kepada Ketua LPPM Universitas Papua beserta staf atas kesempatan serta dukungan yang diberikan sehingga penelitian ini dapat dilaksanakan. 


\section{DAFTAR PUSTAKA}

Avenzora R. (2008). Ekoturisme-Teori dan Praktek. (ID): BRR NADNias.

Kosmaryandi, (2008). dalam Oktami E.A., Tutut S, Harios A. (2018). Partisipasi Masyarakat Dalam Pengembangan Ekowisata Taman Hutan Raya Ir H Djuanda. Media Konservasi Vol. 23 No. 3.

Nikijuluw V.P.H., Renoldy L.P, Paulus B. (2017). Daya Dukung Pariwisata Berkelanjutan Raja Ampat. Conservation International Indonesia.

Nuraini, Arif S, Ekawati S.W. (2018). "Mekanisme Akses dan Kekuasaan Dalam Mmemperkuat Kinerja Institusi Pengelolaan Ekowisata Bahari (Studi Kasus: Kampung Wisata Arborek, Distrik Meos Mansar, Kabupaten Raja Ampat

Puspitasari D. (2019). "Persepsi dan Pengelolaan Homestay di Desa Wisata Wukirsari Bantul" Vol. 9 (Hal. 1-14).

TIES (The International Ecotourism Society). (2002). Quebec Declaration On Ecotourism. Canada

Tsaur \& Lin. (2006). Evaluating ecotourism sustainability from the integrated perspective of resource, communty and tourism. Journal of Tourism Management Vol. $27 \mathrm{hlm}$ 640-653 